\title{
Asuhan Keperawatan Jiwa Dengan Masalah Gangguan Sensori Persepsi : Halusinasi Pada Tn. L Di Jalan Amal Luhur Gang Semar, Kec. Medan Helvetia
}

\author{
Kristin Situmeang, S.Kep
}

Kristin27091996@gmail.com

\section{BAB 1 \\ PENDAHULUAN}

\subsection{Latar Belakang}

Skizofrenia adalah penyakit kronis, parah, dan melumpuhkan, gangguan otak yang ditandai dengan pikiran kacau, waham, halusinasi, dan perilaku aneh (Pardede, J. A, dkk, 2020). Skizofrenia merupakan gangguan jiwa berat yang bersifat kronis, gangguan realitas, gangguan fungsi kognitif serta kesulitan dalam melakukan aktivitas (Keliat dkk, 2014). Berdasarkan WHO (2013) penderita skizofrenia di masyarakat berkisar 1-3 orang permil penduduk di dunia. Sedangkan di Indonesia penderita skizofrenia 1,7 orang permil penduduk indonesia (Riskesdas, 2013). Data yang diperoleh dari Medical Record Rumah Sakit Jiwa Prof.Dr.M.Ildrem Provsu Medan tahun 2017, pasien yang menderita skizofrenia sebanyak 13,846 (85.3\%). Masalah yang sering muncul pada pasien skizofrenia adalah halusinasi (Nyumirah, 2013).

Halusinasi merupakan keadaan seseorang mengalami perubahan dalam pola dan jumlah stimulasi yang diprakarsai secara internal atau eksternal disekitar dengan pengurangan, berlebihan, distorsi, atau kelainan berespon terhadap setiap stimulus (Pardede, Keliat, \& Yulia, 2015). Halusinasi pendengaran paling sering terjadi ketika klien mendengar suara-suara, suara tersebut dianggap terpisah dari pikiran klien sendiri. Isi suara-suara tersebut mengancam dan menghina, sering 
kali suara tersebut memerintah klien untuk melakukan tindakan yang akan melukai klien atau orang lain (Nyumirah, 2013).

Penatalaksaan halusinasi yaitu membantu mengenali halusinasi dengan cara melakukan diskusi dengan klien tentang halusinasinya (apa yang didengar/dilihat), waktu terjadi halusinasi, frekuensi halusinasi, situasi yang menyebabkan halusinasi muncul dan respon klien saat halusinasi muncul, untuk dapat mengontrol halusinasi klien dapat mengendalikan halusinasinya ketika halusinasi kambuh, penerapan ini dapat menjadi jadwal kegiatan sehari-hari yang dapat diterapkan klien yang bertujuan untuk mengurangi masalah halusinasi yang dialami klien dengan gangguan persepsi sensori (halusinasi dengar) (Keliat dkk, 2012).

Klien dengan halusinasi yang telah dikendalikan oleh halusinasinya akan melakukan perilaku yang membahayakan dirinya, orang lain, dan juga lingkungan (Aldam, 2019). Pernyataan ini didukung oleh penelitian Scott (2017) terdapat peningkatan dalam risiko bunuh diri, psikopatologi psikopat, dan nonpsikotik sehingga sulit dalam mencari pekerjaan yang berakibat menurunnya kualitas hidup. Penanganan secara tepat untuk mengatasi dampak dari halusinasi yakni dengan melakukan tindakan asuhan keperawatan dan terapi stimulasi. Asuhan keperawatan yang diberikan pada penderita halusinasi bertujuan untuk meningkatkan kesadaran pasien dalam kehidupan nyata. Terapi stimulasi persepsi dalam mengontrol halusinasi yaitu menghardik dengan menutup telinga, mengontrol halusinasi dengan patuh minum obat, mengajak klien untuk mengobrol dengan orang lain, mengajak klien untuk melakukan aktivitas yang paling disukai (Stuart, Keliat, Pasaribu 2016).

Survei awal pada pembuatan askep pada skizofrenia ini dilakukan di Jalan Amal Luhur Gang Semar, Kec. Medan Helvetia yang ditemukan pasien gangguan sensori persepsi : halusinasi atas nama inisial Tn.L yang pernah di rawat di RSJ. 
Penyebabnya Tn.L dijadikan subjek dikarenakan Tn.L belum sepenuhnya bisa mengatasi halusinasinya. Maka tujuan asuhan keperawatan yang akan di lakukan ialah untuk mengajarkan standar pelaksanaan gangguan sensori persepsi : halusinasi atau cara menghardik halusinasi pada Tn.L.

\subsection{Rumusan Masalah}

Berdasarkan latar belakang masalah tersebut maka dapat dirumuskan masalah sebagai berikut : "Bagaimana Memberikan Asuhan Keperawatan Jiwa Dengan Masalah Halusinasi Pada Tn.L Di Jalan Amal Luhur Gang Semar, Kec. Medan Helvetia”.

\subsection{Tujuan Penulisan}

\subsubsection{Tujuan Umum}

Memberikan asuhan keperawatan jiwa pada Tn.L dengan halusinasi di Jalan Amal Luhur Gang Semar, Kec. Medan Helvetia

\subsubsection{Tujuan Khusus}

a) Mahasiswa mampu mengetahui defenisi, tanda dan gejala, faktor penyebab, mekanisme koping, penatalaksanaan pada pasien dengan Gangguan Sensori Persepsi : Halusinasi

b) Mahasiswa mampu melakukan pengkajian pada pasien dengan Gangguan Sensori Persepsi : Halusinasi

c) Mahasiswa mampu menegakkan diagnosa atau masalah keperawatan pada Tn.L dengan Gangguan Sensori Persepsi : Halusinasi

d) Mahasiswa mampu menetapkan intervensi keperawatan secara menyeluruh pada Tn.L dengan Gangguan Sensori Persepsi : Halusinasi

e) Mahasiswa mampu melakukan tindakan keperawatan yang nyata pada Tn.L dengan Gangguan Sensori Persepsi : Halusinasi 
f) Mahasiswa mampu mengevaluasi sebagai tolak ukur guna menerapkan asuhan keperawatan pada Tn.L dengan Gangguan Sensori Persepsi : Halusinasi

g) Mahasiswa mampu mendokumentasikan asuhan keperawatan pada Tn.L dengan Gangguan Sensori Persepsi : Halusinasi

\subsection{Manfaat}

\section{Pasien}

Diharapkan tindakan yang telah di ajakarkan dapat di terapkan secara mandiri untuk mengontrol halusinasi dan untuk mendukung kelangsungan kesehatan pasien

\section{Keluarga}

Diharapkan keluarga dapat memberikan dukungan moral, emosional dan spiritual serta membantu dalam menerapkan asuhan keperawatan jiwa kepada pasien dengan masalah ganggan sensori persepsi : halusinasi

\section{Institusi Pendidikan}

Bagi institusi pendidikan diharapkan untuk menjadi acuan dalam dalam melakukan kegiatan kemahasiswaan dalam bidang keperawatan jiwa. 


\section{BAB 2 \\ TINJAUAN TEORITIS}

\subsection{Konsep Halusinasi}

\subsubsection{Pengertian}

Halusinasi didefinisikan sebagai suatu tanggapan dari panca indera tanpa adanya rangsangan (stimulus) eksternal Halusinasi merupakan gangguan persepsi dimana pasien mempersepsikan sesuatu yang sebenarnya tidak terjadi. Ada lima jenis halusinasi yaitu pendengaran, penglihatan, penghidu, pengecapan dan perabaan. Halusinasi pendengaran merupakan jenis halusinasi yang paling banyak ditemukan terjadi pada $70 \%$ pasien, kemudian halusinasi penglihatan 20\%, dan sisanya $10 \%$ adalah halusinasi penghidu, pengecapan dan perabaan (Stuart, 2009).

Halusinasi merupakan keadaan seseorang yang mengalami perubahan pola dan jumlah rangsangan yang dimulai secara internal atau eksternal di sekitarnya dengan pengurangan, pembesaran, distorsi, atau ketidaknormalan respon terhadap setiap rangsangan (Pardede, 2020). Faktor-faktor yang mampu mempengaruhi kekambuhan penderita skizofrenia dengan halusinasi meliputi ekspresi emosi keluarga yang tinggi, pengetahuan keluarga yang kurang, ketersediaan pelayanan kesehatan, penghasilan keluarga dan kepatuhan minum obat pasien skizofrenia (Pardede, 2020)

Halusinasi juga merupakan persepsi yang salah atau palsu tetapi tidak ada rangsangan yang menimbulkannya (tidak ada objeknya). Halusinasi muncul sebagai suatu proses panjang yang berkaitan dengan kepribadian seseorang.Karena itu, halusinasi dipengaruhi oleh pengalaman psikologis seseorang (Pardede, 2016). Halusinasi merupakan gangguan atau perubahan persepsi dimana pasien mempersepsikan sesuatu yang sebenarnya tidak terjadi. Suatu penerapan panca indra tanda ada 
rangsangan dari luar. Suatu penghayatan yang dialami suatu persepsi melaluipanca indra tanpa stimullus eksteren : persepsi palsu (Prabowo, 2014).

\subsubsection{Tanda dan Gejala}

Tanda dan gejala halusinasi dinilai dari hasil observasi terhadap pasien serta ungkapan pasien. Tanda dan gejala pasien halusinasi adalah sebagai berikut: (Keliat, 2014)

a. Data Objektif

1) Bicara atau tertawa sendiri

2) Marah-marah tanpa sebab

3) Memalingkan muka ke arah telinga seperti mendengar sesuatu

4) Menutup telinga

5) Menunjuk-nunjuk ke arah tertentu

6) Ketakutan pada sesuatu yang tidak jelas

7) Mencium sesuatu seperti sedang membaui bau-bauan tertentu

8) Menutup hidung

9) Sering meludah

10) Muntah

11) Menggaruk-garuk permukaan kulit

b. Data subjektif

1) Mendengar suara-suara atau kegaduhan

2) Mendengar suara yang mengajak bercakap-cakap

3) Mendengar suara menyuruh melakukan sesuatu yang berbahaya

4) Melihat bayangan, sinar, bentuk geometris, bentuk kartun, melihat hantu atau monster

5) Mencium bau-bauan seperti bau darah, urin, feses, kadang-kadang bau itu menyenangkan

6) Merasakan rasa seperti darah, urin atau feses 
7) Merasa takut atau senang dengan halusinanya

8) Mengatakan sering mengikuti isi perintah halusinasi

\subsubsection{Proses Terjadinya Halusinasi}

Proses terjadinya halusinasi dijelaskan dengan menggunakan konsep stress adaptasi Stuart yang meliputi stressor dari faktor predisposisi dan presipitasi (Prabowo, 2014).

a. Faktor Predisposisi

Faktor predisposisi halusinasi terdiri dari

1) Faktor Biologis :

Adanya riwayat anggota keluarga yang mengalami gangguan jiwa (herediter), riwayat penyakit atau trauma kepala, dan riwayat penggunaan narkotika, psikotropika dan zat adiktif lain (NAPZA).

2) Faktor Psikologis

Memiliki riwayat kegagalan yang berulang.Menjadi korban, pelaku maupun saksi dari perilaku kekerasan serta kurangnya kasih sayang dari orang-orang disekitar atau overprotektif.

3) Sosiobudaya dan lingkungan

Sebagian besar pasien halusinasi berasal dari keluarga dengan sosial ekonomi rendah, selain itu pasien memiliki riwayat penolakan dari lingkungan pada usia perkembangan anak, pasien halusinasi seringkali memiliki tingkat pendidikan yang rendah serta pernah mengalami kegagalan dalam hubungan sosial (perceraian, hidup sendiri), serta tidak bekerja.

b. Faktor Presipitasi

Stressor presipitasi pasien gangguan persepsi sensori halusinasi ditemukan adanya riwayat penyakit infeksi, penyakit kronis atau kelainan struktur otak, adanya riwayat kekerasan dalam keluarga, atau adanya kegagalan-kegagalan dalam hidup, kemiskinan, adanya aturan 
atau tuntutan di keluarga atau masyarakat yang sering tidak sesuai dengan pasien serta konflik antar masyarakat.

c. Stress Lingkungan

Ambang toleransi terhadap tress yang berinteraksi terhadap stressor lingkungan untuk menentukan terjadinya gangguan perilaku.

d. Sumber Koping

Sumber koping mempengaruhi respon individu dalam menanggapi stress (Prabowo, 2014).

e. Perilaku

Respons klien terhadap halusinasi dapat berupa curiga, ketakutan, perasaan tidak aman, gelisah, dan bingung, perilaku menarik diri, kurang perhatian, tidak mampu mengambil keputusan serta tidak dapat membedakan nyata dan tidak.

f. Dimensi fisik

Halusinasi dapat ditimbulkan oleh beberapa kondisi fisik seperti kelelahan yang luar biasa, penggunaan obat-obatan, demam hingga delirium, intoksikasi alkohol dan kesulitan untuk tidur dalamwaktu yang lama.

g. Dimensi emosional

Perasaan cemas yang berlebihan atas dasar problem yang tidak dapat diatasi merupakan penyebab halusianasi itu terjadi, isi dari halusinasi dapat berupa peritah memaksa dan menakutkan.Klien tidak sanggup lagi menentang perintah tersebut hingga dengan kondisi tersebut klien berbuat sesuatu terhadap ketakutan tersebut.

h. Dimensi intelektual

Dalam dimensi intelektual ini menerangkan bahwa individu dengan halusinasi akan memperlihatkan adanya penurunan fungsi ego. Pada awalnya halusinasi merupakan usha dari ego sendiri untuk melawan impuls yang menekan, namun merupakan suatu hal yang 
menimbulkan kewaspadaan yang dapat mengambil seluruh perhatian klien dan tak jarang akan mengotrol semua perilaku klien.

i. Dimensi social

Klien mengalami gangguan interaksi sosial dalam fase awal dan comforting, klien menganggap bahwa hidup bersosialisasi dialam nyata sangat membahayakan. Klien asyik dengan dengan halusinasinya, seolah-olah ia merupakan tempat untuk memenuhi kebutuhan akan interaksi sosial, kontrol diri dan harga diri yang tidak didapatkan dalam dunia nyata. Isi halusinasi dijadikan kontrol oleh individu tersebut, sehingga jika perintah halusinasiberupa ancaman, dirinya atau orang lain individu cenderung keperawatan klien dengan mengupayakan suatu proses interkasi yang menimbulkan pengalaman interpersonal yang memuaskan, serta mengusahakan klien tidak menyendiri sehingga klien selalu berinteraksi dengan lingkungannya dan halusinasi tidak berlangsung.

j. Dimensi spiritual

Secara spiritualklien halusinasi mulai dengan kehampaan hidup, rutinitas, tidak bermakna, hilangnya aktivitas ibadah dan jarang berupaya secara spiritual untuk menyucikan diri, irama sirkardiannya terganggu (Damaiyanti, 2014).

\subsubsection{Jenis-jenis Halusinasi}

Menurut Pardede et all (2021) jenis halusinasi antara lain :

1. Halusinasi pendengaran (auditorik) $70 \%$ Karakteristik ditandai dengan mendengar suara, teruatama suara - suara orang, biasanya klien mendengar suara orang yang sedang membicarakan apa yang sedang dipikirkannya dan memerintahkan untuk melakukan sesuatu.

2. Halusinasi penglihatan (visual) $20 \%$ Karakteristik dengan adanya stimulus penglihatan dalam bentuk pancaran cahaya, gambaran 
geometrik, gambar kartun dan / atau panorama yang luas dan kompleks. Penglihatan bisa menyenangkan atau menakutkan.

3. Halusinasi penghidu (olfactory) Karakteristik ditandai dengan adanya bau busuk, amis dan bau yang menjijikkan seperti: darah, urine atau feses. Kadang - kadang terhidu bauharum.Biasanya berhubungan dengan stroke, tumor, kejang dan dementia.

4. Halusinasi peraba (tactile) Karakteristik ditandai dengan adanya rasa sakit atau tidak enak tanpa stimulus yang terlihat. Contoh : merasakan sensasi listrik datang dari tanah, benda mati atau orang lain.

5. Halusinasi pengecap (gustatory) Karakteristik ditandai dengan merasakan sesuatu yang busuk, amis dan menjijikkan, merasa mengecap rasa seperti rasa darah, urin atau feses.

6. Halusinasi cenesthetik Karakteristik ditandai dengan merasakan fungsi tubuh seperti darah mengalir melalui vena atau arteri, makanan dicerna atau pembentukan urine.

7. Halusinasi kinesthetic Merasakan pergerakan sementara berdiri tanpa bergerak

Tabel 2.1 Karakteristik Halusinasi (Direja, 2011)

\begin{tabular}{|l|l|}
\hline \multicolumn{1}{|c|}{ Jenis Halusinasi } & \multicolumn{1}{|c|}{ Karakteristik } \\
\hline Pendengaran & $\begin{array}{l}\text { Mendengar suara-suara atau kebisingan, paling } \\
\text { sering suara orang, suara berbentuk kebisingan } \\
\text { yang kurang keras sampai kata- kata yang jelas } \\
\text { berbicara tentang klien, bahkan sampai } \\
\text { percakapan lengkap antara dua orang atau } \\
\text { lebih. Pikiran yang didengar klien dimana klien } \\
\text { disuruh untuk melakukan sesuatu yang kadang- } \\
\text { kadang membahayakan. }\end{array}$ \\
\hline
\end{tabular}




\begin{tabular}{|l|l|}
\hline Penglihatan & $\begin{array}{l}\text { Stimulus visual dalam bentuk kelihatan cahaya, } \\
\text { gambaran geometris, gambaran kartun, } \\
\text { bayangan yang rumit dan kompleks. Bayangan } \\
\text { bisa menyenangkan atau menakutkan seperti } \\
\text { melihat monster. }\end{array}$ \\
\hline Penghidu & $\begin{array}{l}\text { Menghirup bau-bauan tertentu seperti bau } \\
\text { darah, bau urin, atau bau feses, umumnya bau- } \\
\text { bauan yang tidak menyenangkan. Halusinasi } \\
\text { penghidu sering akibat dari stroke, tumor, } \\
\text { kejang atau dimensia. }\end{array}$ \\
\hline Pengecapan & $\begin{array}{l}\text { Merasa mengecap rasa sesuatu seperti darah, } \\
\text { urin atau feses. }\end{array}$ \\
\hline Perabaan & $\begin{array}{l}\text { Mengalami nyeri atau ketidaknyamanan tanpa } \\
\text { stimulus yang jelas. Rasa tersetrum listrik yang } \\
\text { datang dari tanah, benda mati atau orang lain. }\end{array}$ \\
\hline Cenesthetics & $\begin{array}{l}\text { Merasakan fungsi tubuh seperti aliran darah di } \\
\text { pena atau arteri, pencernaan makanan atau }\end{array}$ \\
\hline
\end{tabular}

\subsubsection{Tahapan Halusinasi}

a) Tahap I :

Halusinasi bersifat menyenangkan, tingkat ansietas pasien sedang. Pada tahap ini halusinasi secara umum menyenangkan (Prabowo, 2014)

Karakteristik :

Karakteristik tahap ini ditandai dengan adanya perasaan bersalah dalam diri pasien dan timbul perasaan takut. Pada tahap ini pasien mencoba menenangkan pikiran untuk mengurangi ansietas. Individu 
mengetahui bahwa pikiran dan sensori yang dialaminya dapat dikendalikan dan bisa diatasi (non psikotik).

Perilaku yang teramati :

1. Menyeringai / tertawa yang tidak sesuai

2. Menggerakkan bibirnya tanpa menimbulkan suara

3. Respon verbal yang lambat

4. Diam dan dipenuhi oleh sesuatu yang mengasyikan

b) Tahap II :

Halusinasi bersifat menyalahkan, pasien mengalami ansietas tingkat berat dan halusinasi bersifat menjijikkan untuk pasien.

Karakteristik :

Pengalaman sensori yang dialami pasien bersifat menjijikkan dan menakutkan, pasien yang mengalami halusinasi mulai merasa kehilangan kendali, pasien berusaha untuk menjauhkan dirinya dari sumber yang dipersepsikan, pasien merasa malu karena pengalaman sensorinya dan menarik diri dari orang lain (nonpsikotik).

Perilaku yang teramati :

1. Peningkatan kerja susunan saraf otonom yang menunjukkan timbulnya ansietasseperti peningkatan nadi, tekanan darah dan pernafasan

2. Kemampuan kosentrasi menyempit.

3. Dipenuhi dengan pengalaman sensori, mungkin kehilangan kemampuan untuk membedakan antara halusinasi dan realita

c) Tahap III :

Pada tahap ini halusinasi mulai mengendalikan perilaku pasien, pasien berada pada tingkat ansietas berat. Pengalaman sensori menjadi menguasai pasien.

Karakteristik :

Pasien yang berhalusinasi pada tahap ini menyerah untuk melawan pengalaman halusinasi dan membiarkan halusinasi menguasai dirinya. 
Isi halusinasi dapat berupa permohonan, individu mungkin mengalami kesepian jika pengalaman tersebut berakhir (Psikotik).

Perilaku yang teramati :

1. Lebih cenderung mengikuti petunjuk yang diberikan oleh halusinasinya dari pada menolak.

2. Kesulitan berhubungan dengan orang lain.

3. Rentang perhatian hanya beberapa menit atau detik, gejala fisik dari ansietas berat seperti : berkeringat, tremor, ketidakmampuan mengikuti petunjuk.

d) Tahap IV :

Halusinasi pada saat ini, sudah sangat menaklukkan dan tingkat ansietas berada pada tingkat panik. Secara umum halusinasi menjadi lebih rumit dan saling terkait dengan delusi.

Karakteristik :

Pengalaman sensori menakutkan jika individu tidak mengikuti perintah halusinasinya. Halusinasi bisa berlangsung dalam beberapa jam atau hari apabila tidak diintervensi (psikotik).

Perilaku yang teramati :

1. Perilaku menyerang - teror seperti panik.

2. Sangat potensial melakukan bunuh diri atau membunuh orang lain.

3. Amuk, agitasi dan menarik diri.

4. Tidak mampu berespon terhadap petunjuk yang komplek

5. Tidak mampu berespon terhadap lebih dari satu orang

\subsubsection{Rentang Respon Halusinasi}

Rentang Respon neurobiologis

Respons adatif Respons maladatif

a. Pikiran logis

b. Persepsi akurat

c. Emosi konsisten dengan pengalaman

d. Hubungan sosial harmonis
a. Kadang proses pikir terganggu
b. Ilusi
c. Emosi berlebihan/ kurang
d. Perilaku tiałk biasa
e. Menarik diri
a. Gangguan proses pikir (waham)
b. Halusinasi
c. Kerusakan proses emosi
d. Perilaku tidak terorganisir
e. Isolasi sosial 
Halusinasi merupakan salah satu respon maladaptif individu yang berada dalam rentang respon neurobiologis (Stuart dan Laraia, 2005). Ini merupakan respon persepsi paling maladaptif. Jika klien sehat maka persepsinya akurat, mampu mengidentifikasi dan menginterorestasikan stimulus berdasarkan informasi yang diterima melalui pancaindra (pendengaran, penglihatan, penghidu, pengecapan, dan perabaan), klien dengan halusinasi mempersepsikan suatu stimulus pancaindra walaupun sebenarnya stimulus tersebut tidak ada. Respon individu (yang karena suatu hal mengalami kelainan persepsi) yaitu salah mempersepsikan stimulus yang diterimanya yang disebut dengan ilusi. Klien mengalami ilusi jika interpretasi yang dilakukan terhadap stimulus pancaindera tidak akurat sesuai dengan stimulus yang diterima. Respon tersebut digambarkan seperti gambar diatas.

\subsubsection{Faktor Yang Mempengaruhi Terjadinya Halusinasi}

Halusinasi merupakan salah satu gejala dalam menentukan diagnosis klien yang mengalami psikotik, khususnya skizofrenia. Halusinasi dipengaruhi oleh faktor (Stuart dan Laraia, 2005), dibawah ini antara lain :

a) Faktor Predisposisi

Adalah faktor resiko yang mempengaruhi jenis dan jumlah sumber yang dapat di bangkitkan oleh individu untuk mengatasi stress. Diperoleh baik dari klien maupun keluarganya, mengenai faktor perkembangan sosial kultural, biokimia, psikologis, dan genetik. Beberapa faktor predisposisi yang berkontribusi pada munculnya respon neurobiology seperti pada halusinasi antara lain :

\section{Faktor Genetik}

Telah diketahui bahwa secara genetik skizofrenia diturunkan melalui kromosom - kromosom tertentu. Namun demikian, kromosom yang keberapa yang menjadi faktor penentu gangguan ini sampai sekarang masih dalam tahap penelitian. Anak kembar 
identik memiliki kemungkinan mengalami skizofrenia sebesar $50 \%$ jika salah satunya mengalami skizofrenia, sementara dizygote peluangnya sebesar $15 \%$. Seorang anak yang salah satunya orang tuanya mengalami skizofrenia berpeluang $15 \%$ mengalami skizofrenia, sementara bila kedua orang tuanya skizofrenia maka peluangnya menjadi $35 \%$.

2. Faktor Perkembangan

Jika tugas perkembangan mengalami hambatan dan hubungan interpersonal terganggu, maka individu akan mengalami stress dan kecemasan.

\section{Faktor neurobiology}

Ditemukan bahwa kortex pre frontal dan kortex limbic pada klien dengan skizofrenia tidak pernah berkembang penuh. Ditemukan juga pada klen skizofrenia terjadi penurunan volume dan fungsi otak yang abnormal. Neurotransmitter juga tidak ditemukan tidak normal, khususnya dopamine, serotonin dan glutamat.

4. Faktor biokimia

Mempunyai pengaruh terhadap terjadinya gangguan jiwa. Dengan adanya stress yang berlebihan yang dialami seseorang, maka tubuh akan menghasilkan suatu zat yang dapat bersifat halusinogenik neurokimia seperti Buffofenon dan Dimetytranferase (DMP).

5. Faktor Sosiokultural

Berbagi faktor dimasyarakat dapat menyebabkan seorang merasa disingkirkan oleh kesepian terhadap lingkungan tempat klien dibesarkan.

6. Psikologis

Beberapa kondisi psikologis yang menjadi faktor predisposisi skizofrenia, anatara lain anak yang diperlakukan oleh ibu yang pencemas, terlalu melindungi, dingin dan tidak berperasaan, sementara ayah yang mengambil jarak dengan anaknya. Sementara 
itu hubungan interpersonal yang tidak harmonis serta adanya peran ganda yang bertentangan dan sering diterima oleh anak akan mengakibatkan stress dan kecemasan yang tinggi dan berakhir dengan gangguan orientasi realitas.

b) Faktor presipitasi

Yaitu suatu stimulus yang dipersepsikan oleh individu sebagai tantangan, ancaman/tuntutan yang memerlukan energi ekstra untuk koping. Adanya rangsang lingkungan yang sering yaitu seperti partisipasi klien dalam kelompok, terlalu lama diajak komunikasi dan suasana sepi/isolasi sering sebagai pencetus terjadinya halusinasi karena hal tersebut dapat meningkatkan stress dan kecemasan yang merangsang tubuh mengeluarkan zat halusinogenik. Disamping itu juga oleh karena proses penghambatan dalam proses transduksi dari impuls yang menyebabkan terjadinya penyimpangan dalam proses interpretasi dan interkoneksi sehingga dengan demikian faktor - faktor pencetus respon neurobiologis dapat dijabarkan sebagai berikut :

1. Berlebihnya proses informasi pada sistem syaraf yang menerimadan memproses informasi dithalamus dan frontal otak

2. Mekanisme penghantaran listrik di syaraf terganggu (mekanismegatting abnormal).

3. Gejala - gejala pemicu seperti kondisi kesehatan, lingkungan, sikap, dan perilaku

\subsubsection{Validasi Informasi Tentang Halusinasi}

Halusinasi benar-benar nyata dirasakan oleh klien yang mengalaminya, seperti mimpi saat tidur. Klien mungkin tidak punya cara untuk menentukan persepsi tersebut secara nyata. Sama halnya seperti seseorang yang mendengarkan siaran ramalan cuaca dan tidak lagimeragukan orang yang berbicara tentang cuaca tersebut. Ketidakmampuan untuk mempersepsikan stimulus secara riil dapat menyulitkan kehidupan klien. 
Karenanya halusinasi menjadi prioritas untuk segera diatasi. Sangat penting untuk memberi kesempatan klien untuk menjelaskan tentang halusinasi yang dialaminya secara leluasa. Perawat membutuhkan kemampuan untuk berbicara tentang halusinasi karena dengan perbincangan halusinasi dapat menjadi indikator sejauh mana gejala psikotik klien diatasi. Untuk memfasilitasinya klien perlu dibuat nyaman untuk menceritakan perihal halusinasinya. Klien yang mengalami halusinasi sering kecewa karena mendapatkan respon negatif ketika mereka menceritakan halusinasinya kepada orang lain. Karenanya banyak klien kemudian enggan untuk menceritakan pengalaman-pengalaman aneh halusinasinya (Prabowo, 2014).

Pengalaman halusinasi menjadi masalah untuk dibicarakan dengan orang lain. Kemampuan untuk bercakap - cakap tentang halusinasi yang dialami oleh klien sangat penting untuk memastikan dan memvalidasi pengalaman halusinasi tersebut. Perawat harus memiliki ketulusan dan perhatian yang penuh untuk dapat memfasilitasi percakapan tentang halusinasi. Perilaku klien yang mengalami halusinasi sangat tergantung pada jenis halusinasinya, apakah halusinasinya merupakan halusinasi pendengaran, penglihatan, penghidu, pengecapan, perabaan, kinestetik, cenesthetic. Apakah perawat mengidentifikasi adanya tanda - tanda dan perilaku halusinasi, maka pengkajian selanjutnya harus dilakukan tidak hanya sekedar mengetahui jenis halusinasinya saja. Validasi informasi tentang halusinasi yang dilakukan meliputi :

1. Isi Halusinasi, yang dialami oleh klien. Ini dapat dikaji dengan menanyakan suara siap yang didengar dan apa yang dikatakan berkata jika halusinasi yang dialami adalah halusinasi dengar. Bentuk bayanganbagaimana yang dilihat klien bila jenis halusinasinya adalah halusinasi penglihatan, bau apa yang dicium jika halusinasinya adalah halusinasi penghidu, rasa apa yang dikecap untuk halusinasi 
pengecapan, atau merasakan apa dipermukaan tubuh bila mengalami halusinasi perabaan.

2. Waktu dan Frekuensi Halusinasi, ini dapat dikaji dengan menanyakan kepada klien kapan pengalaman halusinasi muncul, berapahari sekali, seminggu atau sebulan pengalaman halusinasi itu muncul. Informasi ini penting untuk mengidentifikasi pencetus halusinasi dan menentukan bilamana klien perlu diperhatikan saat mengalami halusinasi.

3. Situasi pencetus Halusinasi, perawat perlu mengidentifikasi situasi yang dialami klien sebelum mengalami halusinasi. Ini dapat dikaji dengan menanyakan kepada klien peristiwa atau kejadian yang dialami sebelum halusinasi ini muncul. Selain itu perawat juga bisa mengobservasi apa yang dialami klien menjelang muncul halusinasi untuk memvalidasi pernyataan klien.

4. Respon klien, untuk menentukan sejauh mana halusinasi telah mempengaruhi klien, bisa dikaji dengan menanyakan apa yang dilakukan klien saat mengalami pengalaman halusinasi. Apakah klien masih bisa mengontrol stimulasi halusinasi atau sudah tidak berdayalagi terhadap halusinasi (Stuart dan Laraia, 2005).

\subsection{Konsep Asuhan Keperawatan Halusinasi}

Gangguan persepsi sensori : Halusinasi merupakan salah satu masalah keperawatan yang dapat ditemukan pada pasien gangguan jiwa. Bagian ini berisi pedoman agar perawat dapat memberikan asuhan keperawatan kepada pasien yang mengalami gangguan jiwa (Keliat B. A, dkk, 2012).

\section{Identitas Klien}

Identitas ditulis lengkap meliputi nama, usia dalam tahun, alamat,pendidikan, agama, status perkawinan, pekerjaan, jenis kelamin, nomor rekam medis dan diagnosa medisnya. 


\section{Alasan Masuk}

Menanyakan kepada klien/keluarga/pihak yang berkaitan dan tulis hasilnya, apa yang menyebabkan klien datang kerumah sakit, apa yang sudah dilakukan oleh klien/keluarga sebelumnya atau dirumah untuk mengatasi masalah ini dan bagaimana hasilnya. Klien dengan halusinasi biasanya dilaporkan oleh keluarga bahwa klien sering melamun, menyendiridan terlihat berbicara sendiri, tertawa sendiri.

3. Riwayat Penyakit Sekarang

Menanyakan riwayat timbulnya gejala gangguan jiwa saat ini, penyebab munculnya gejala, upaya yang dilakukan keluarga untuk mengatasi dan bagaimana hasilnya.

\section{Faktor Predisposisi}

Menanyakan apakah klien pernah mengalami gangguan jiwa dimasa lalu, pengobatan yang pernah dilakukan sebelumnya, adanya trauma masa lalu, faktor genetik dan silsilah orang tuanya dan pengalaman masa laluyang tidak menyenangkan.

5. Pemeriksaan Fisik

Mengkaji keadaan umum klien, tanda-tanda vital, tinggi badan/ berat badan, ada/tidak keluhan fisik seperti nyeri dan lain-lain.

6. Pengkajian Psikososial

a) Genogram

Membuat genogram beserta keterangannya untuk mengetahui kemungkinan adanya riwayat genetik yang menyebabkan menurunkan gangguan jiwa.

b) Konsep Diri

1. Citra tubuh, bagaimana persepsi klien terhadap tubuhnya, bagian tubuhnya yang paling/tidak disukai.

2. Identitas diri, bagaimana persepsi tentang status dan posisi klien sebelum dirawat, kepuasan klien terhadap suatu/posisi tersebut, kepuasan klien sebagi laki-laki atau perempuan. 
3. Peran, bagaimana harapan klien terhadap tubuhnya, posisi, status, tugas/peran yang harapannya dalam keluarga, kelompok, masyarakat dan bagaimana kemampuan klien dalam melaksanakan tugas/peran tersebut.

4. Ideal diri, bagaimana harapan klien terhadap tubuhnya, posisi, status, tugas/peran dan harapan klien terhadap lingkungan.

5. Harga diri, bagaimana persepsi klien terhadap dirinya dalam hubungannya dengan orang lain sesuai dengan kondisi dan bagaimana penilaian/ penghargaan orang lain terhadap diri dan lingkungan klien.

c) Hubungan Sosial

Mengkaji siapa orang yang berarti/terdekat dengan klien, bagaimana peran serta dalam kegiatan dalam kelompok/masyarakat serta ada/tidak hambatan dalam berhubungan dengan orang lain.

d) Spiritual

Apa agama/keyakinan klien. Bagaimana persepsi, nilai, norma, pandangan dan keyakinan diri klien, keluarga dan masyarakat setempat tentang gangguan jiwa sesui dengan norma budaya dan agama yang dianut.

e) Status Mental

1. Penampilan

Observasi penampilan umum klien yaitu penampilan usia, cara berpakaian, kebersihan, sikap tubuh, cara berjalan, ekspresi wajah, kontak mata.

2. Pembicaraan

Bagaimana pembicaraan yang didapatkan pada klien, apakah cepat, keras. Gagap, inkoheren, apatis, lambat, membisu dan lain-lain.

3. Aktivitas motorik (psikomotor)

Aktivitas motorik berkenaan dengan gerakan fisik perlu dicacat dalam hal tingkat aktivitas (latergik, tegang, gelisah, agitasi), jenis (TIK, tremor) dan isyarat tubuh yang tidak wajar. 
4. Afek dan emosi

Afek merupakan nada perasaan yang menyenangkan atau tidak menyenangkan yang menyertai suatu pikiran dan berlangsung relatif lama dan dengan sedikit komponen fisiologis/fisik serta bangga, kecewa. Emosi merupakan manifestasi afek yang ditampilkan/diekspresikan keluar, disertai banyak komponen fisiologis dan berlangsung relatif lebih singkat/spontan seperti sedih, ketakutan, putus asa, kuatir atau gembira berlebihan.

5. Interaksi selama wawancara

Bagaimana respon klien saat wawancara, kooperatif/tidak, bagaimana kontak mata dengan perawat dan lain-lain.

6. Persepsi sensori

Memberikan pertanyaan kepada klien seperti "apakah anda sering mendengar suara saat tidak ada orang? Apa anda mendengar suara yang tidak dapat anda lihat? Apa yang anda lakukan oleh suara itu. Memeriksa ada/ tidak halusinasi, ilusi.

7. Proses piker

Bagaimana proses pikir klien, bagaimana alur pikirnya (koheren/inkoheren), bagaimana isi pikirannya realitas/tidak.

8. Kesadaran

Bagaimana tingkat kesadaran klien menurun atau meninggi.

9. Orientasi

Bagaimana orientasi klien terhadap waktu, tempat dan orang

10. Memori

Apakah klien mengalami gangguan daya ingat, seperti: efek samping dari obat dan dari psikologis

\section{Tingkat konsentrasi dan berhitung}

Apakah klien mengalami kesulitan saat berkonsentrasi, bagaimana kemampuan berhitung klien, seperti: disaat ditanya apakah klien menjawab pentanyaan sesuai dengan yang ditanyakan oleh observer. 
12. Kemampuan penilaian

\section{Daya fikir diri}

Biasanya klien mengingkari penyakit yang dideritanya

f) Kebutuhan persiapan pulang

1. Makan

Biasanya klien tidak mengalami perubahan

\section{2. $\mathrm{BAB} / \mathrm{BAK}$}

Biasanya klien dengan halusinasi tidak ada gangguan

\section{Mandi}

Biasanya klien jarang mandi, tidak menyikat gigi, jarang mencuci rambut dan bercukur atau berhias. Badan klien sangat bau dan kotor, dan klien hanya melakukan kebersihan diri jika disuruh.

4. Berpakaian

Biasanya klien jarang mengganti pakaian, dan tidak mau berdandan. Klien tidak mampu mengenakan pakaian dengan sesuai dan klien tidak mengenakan alas kaki

5. Istirahat dan tidur

Biasanya klien tidak melakukan persiapan sebelum tidur, seperti: menyikat gigi, cucui kaki, berdoa. Dan sesudah tidur seperti: merapikan tempat tidur, mandi atau cuci muka dan menyikat gigi. Frekuensi tidur klien berubah-ubah, kadang nyenyak dan kadang gaduh atau tidak tidur.

6. Penggunaan obat

Biasanya klien mengatakan minum obat 3 kali sehari dan klien tidak mengetahui fungsi obat dan akibat jika putus minum obat.

7. Pemeliharaan kesehatan

Biasanya klien tidak memperhatikan kesehatan nya, dan tidak peduli tentang bagai mana cara yang baik untuk merawat dirinya. 
8. Aktifitas didalam rumah

Biasanya klien mampu merencanakan, mengolah, dan menyajikan makanan, merapikan rumah, mencuci pakaian sendiri dan mengatu rbiaya sehari-hari.

g) Mekanisme koping

Biasanya klien menggunakan respon maldaptif yang ditandai dengan tingkah laku yang tidak terorganisir, marah-marah bila keinginannya tidak terpenuhi, memukul anggota keluarganya, dan merusak alat-alat rumah tangga.

h) Masalah psikologis dan lingkungan

Biasanya klien merasa ditolak dan mengalami masalah interaksi dengan lingkungan

i) Pengetahuan

Biasanya klien dengan prilaku kekerasan kurang pengetahuan tentang penyakitnya,dan klientidak mengetahui akibat dari putus obat dan fungsi dari obat yang diminumnya. 


\section{BAB 3}

\section{TINJAUAN KASUS}

Ruang rawat : Jalan Amal Luhur Gang Semar, Kec. Medan Helvetia

Tanggal MRS : 17 Febuari 2021

\subsection{Identitas Klien}

$\begin{array}{lll}\text { Inisial } & : & \text { Tn.L } \\ \text { Jenis kelamin } & : & \text { Laki-Laki } \\ \text { Umur } & : & 69 \text { Tahun } \\ \text { Agama } & : & \text { Islam } \\ \text { Status } & : & \text { Menikah } \\ \text { Tanggal pengkajian } & : & 17 \text { Febuari } 2021 \\ \text { Informan } & : & \text { Status klien dan komunikasi dengan klien }\end{array}$

\subsection{Alasan Masuk Rumah Sakit}

Alasan pasien masuk rumah sakit adalah pasien berbicara dan tertawa sendiri, pasien juga sering membaca koran dan menulis (tetapi hanya pasien yang mengerti apa yang dibaca dan yang ditulis). Ketika pertama kali masuk kerumah sakit pasien sempat marah-marah kepada lingkungan sekitar. Pasien juga tidak pernah mandi, ketika pasien disuruh mandi pasien marah-marah.

\subsection{Faktor Predisposisi}

Pasien sebelumnya tidak pernah ada riwayat gangguan jiwa. Pertama kali pasien mengalami gangguan jiwa ketika pasien berjualan rokok di pajak seikambing, kebetulan pada waktu itu usaha Tn.L sangat laris ia juga tulang punggung keluarganya. Keluarga mengatakan pada saat pasien ingin berangkat bekerja pasien tidak mau, pasien juga membuang semua usaha rokoknya. Pasien juga mengatakan "aku tidak ingin jualan lagi sambil membuang semua rokok" pasien 
juga sempat marah-marah ketika disuruh bekerja. Pasien juga sempat dibawa berobat kampung (dukun) tetapi tidak ada perubahan pada pasien tersebut, dan akhirnya keluarga memutuskan untuk membawa pasien ke rumah sakit jiwa. Ketika pasien dirawat di rumah sakit jiwa selama 10 hari pasien ada perubahan dan dokter juga menyuruh keluarga membawa pulang pasien. Sepulang dari rumah sakit pasien hanya minum obat secara teratur selama 1 bulan saja, pasien mengalami gangguan jiwa \pm 20 tahun. Selama 20 tahun pasien tidak pernah mengkonsumsi obat secara teratur lagi. Pasien sering mendengar suara-suara dari telinganya bahkan pasien sering berbicara dengan orang yang tidak tampak. Terkadang pasien tertawa ketika mendegarkan halusinasinya. Pasien juga seperti ada dunia lain, setiap harinya pasien selalu pergi keluarga rumah. Pasien selalu singgah di kede-kedei yang menurut pasien nyaman, ketika pasien singgah pasien selalu membaca dan menulis. Keluarga pasien tidak ada yang pernah mengalami gangguan jiwa.

Masalah Keperawatan : Halusinasi pendengaran dan penglihatan

\subsection{Fisik}

Klien tidak memiliki keluhan fisik, saat dilakukan pemeriksaan tanda-tanda vital, didapatkan hasil TD : 110/80 mmHg ; $\mathrm{N}: 80 x / \mathrm{i} ; \mathrm{S}: 36,5^{\circ} \mathrm{C} ; \mathrm{P}: 22 \mathrm{x} / \mathrm{i}$. Klien memiliki tinggi badan $158 \mathrm{~cm}$ dan berat badan $55 \mathrm{Kg}$.

\subsection{Psikososial}

\subsubsection{Genogram}

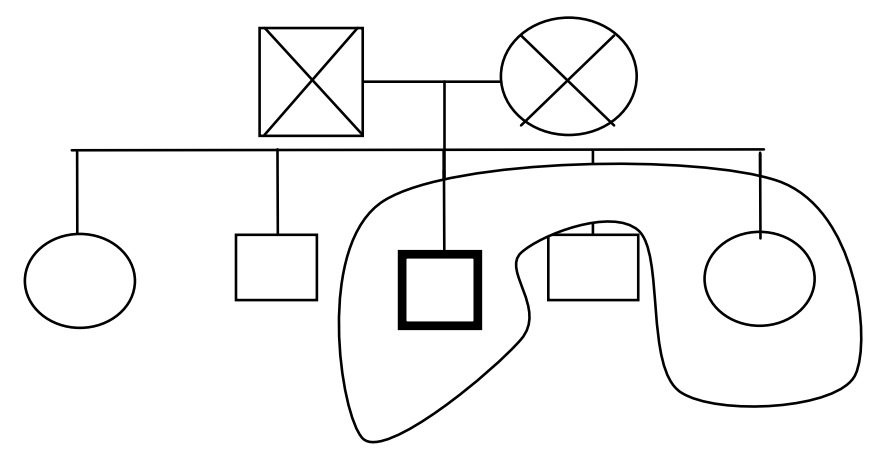


Px tinggal di Jalan Amal Luhur, Gang Semar, Kec. Medan Helvetia Sumatera Utara. Klien mempunyai ayah satu dan ibu satu, serta mempunyai kakak satu, abang satu, satu adek laki-laki dan satu adek perempuan. klien adalah anak ke tiga dari lima bersaudara, klien mengalami gangguan jiwa dan keluarga dalam keadaan sehat fisik dan psikologis serta tidak mengalami gangguan jiwa (sehat jiwa).

\section{Keterangan :}

: perempuan

$\square$ : laki-laki

$\square$ : Tn. L

$\Pi$ : garis keturunan

$\sqcup$ : garis perkawinan

:

$X$ : meninggal

\subsubsection{Konsep Diri}

a. Gambaran diri : Klien menyukai seluruh tubuhnya dan tidak ada yang cacat

b. Identitas : Klien anak ke 3 dari 5 bersaudara, klien lulusan SMA yang saat ini tidak memiliki pekerjaan

c. Peran : Klien berperan sebagai kepala keluarga dan abang, tetapi tidak lagi selama gangguan jiwa

d. Ideal diri : Klien ingin cepat sembuh

e. Harga diri : Klien merasa tidak berarti lagi dalam keluarganya Masalah Keperawatan : Harga diri rendah

\subsubsection{Hubungan Sosial}

1. Orang yang berarti : orang yang berarti dalam kehidupan pasien adalah adik perempuannya dikarenakan adik perempuannya yang menjaga dan merawat pasien tersebut 
2. Peran serta dalam kegiatan kelompok/masyarakat : klien kooperatif dan ramah pada masyarakat lingkungan sekitar rumahnya. Pasien tidak pernah mengikuti kegiatan kelompok lingkungan rumah

3. Hambatan dalam berbuhungan dengan orang Lain : klien tidak ada hambatan dalam berhubungan dengan oranglain.

Masalah Keperawatan : Tidak ada masalah keperawatan

\subsubsection{Spiritual}

1. Nilai dan Keyakinan : Klien beragama islam dan yakin kepada Allah SWT

2. Kegiatan Ibadah : Klien tidak pernah ibadah

Masalah keperawatan : Tidak Ada Masalah Keperawatan

\subsubsection{Status Mental}

1. Penampilan

Penjelasan : Klien berpenampilan jorok, tidak pernah mandi

Masalah keperawatan : Defisit perawatan diri

2. Pembicaraan

Penjelasan : Lancar dan selalu menjawab jika

ditanya

Masalah keperawatan : Tidak Ada Masalah Keperawatan

3. Aktivitas Motorik

Penjelasan : Klien tampak biasa saja dan santai

Masalah Keperawatan: Tidak Ada Masalah Keperawatan

4. Suasana perasaan

Penjelasan : Klien tampak biasa saja seperti tidak ada masalah

Masalah keperawatan : Tidak Ada Masalah Keperawatan

5. Afek

Penjelasan : Labil disaat ada suara bisikan klien berbicara sendiri, senyum-senyum sendiri, dan kadang gelisah 
Masalah keperawatan : Halusinasi pendengaran

6. Interaksi selama wawancara

Penjelasan : Kooperatif dan mau menjawab

pertanyaan-pertanyaan

Masalah keperawatan : Tidak Ada Masalah Keperawatan

7. Persepsi

Penjelasan : Klien mengatakan bahwa ada suarasuara yang selalu mengajak pasien berbicara. Klien terkadang tersenyum setalah mendengar halusinasi, klien juga terkadang seperti berbicara bersama teman yang tak tampak pada orang lain. Klien juga pernah menyuruh pergi halusinasinya

Masalah keperawatan : Gangguan persepsi sensori : halusinasi penglihatan dan pendengaran

8. Proses Pikir

Penjelasan : Klien mampu menjawab apa yang ditanya

Masalah keperawatan : Tidak ada masalah keperawatan

9. Isi pikir

Penjelasan : Klien tidak dapat mengontrol isi pikirnya, klien mengalami gangguan isi pikir

Masalah Keperawatan: Waham Kebesaran

10. Tingkat kesadaran

Penjelasan $\quad$ Klien tidak mengalami gangguan orientasi, klien mengenali waktu, orang dan tempat.

Masalah keperawatan : Tidak Ada Masalah Keperawatan

11. Memori

Penjelasan $\quad$ : Klien mampu menceritakan kejadian di masa lalu dan yang baru terjadi Masalah Keperawatan: Tidak Ada Masalah Keperawatan 
12. Tingkat konsentrasi berhitung

Penjelasan : Klien mampu berkonsentrasi dalam perhitungan sederhana tanpa bantuan orang lain.

Masalah keperawatan : Tidak Ada Masalah Keperawatan

13. Kemampuan penilaian

Penjelasan : Klien dapat membedakan hal yang baik dan

yang buruk

Masalah keperawatan : Tidak Ada Masalah Keperawatan

14. Daya tilik diri

Penjelasan : Klien mengatakan bahwa dirinya tidak mengerti dengan penyakitnya

Masalah keperawatan : Kurangnya informasi

\subsection{Mekanisme Koping}

Klien mengalami mekanisme koping adaptif yaitu klien dapat berbicara baik dengan orang lain.

\subsection{Masalah Psikososial dan Lingkungan}

Klien mengatakan sulit berteman dengan orang lain karena klien sibuk untuk bekerja dan tidak sempat untuk melakukan kumpul-kumpul bersama masyarakat sekitar.

\subsection{Pengetahuan Kurang Tentang Gangguan Jiwa}

Klien tidak mengetahui tentang penyakit gangguan jiwa danklien tidak tahu obat apa yang harus diminum untuk mengatasi gangguan jiwanya. 


\subsection{Analisa Data}

\begin{tabular}{|c|c|c|}
\hline No & Analisa Data & Masalah keperawatan \\
\hline 1 & $\begin{array}{l}\text { DS : } \\
\text { - Keluarga mengatakan klien } \\
\text { sering berbicara sendiri dan } \\
\text { tertawa sendiri } \\
\text { - Klien sering mendengar suara- } \\
\text { suara yang menyuruhnya untuk } \\
\text { pergi bekerja } \\
\text { - Klien terkadang tampak senang } \\
\text { ketika halusinasinya datang } \\
\text { - Klien sering mendengar suara- } \\
\text { suara ketika pagi hari, dan } \\
\text { sebelum tidur malam klien } \\
\text { sering berbicara sendiri terlebih } \\
\text { dahulu } \\
\text { DO : } \\
\text { - Klien tampak berbicara sendiri } \\
\text { - Mulut klien tampak komat- } \\
\text { - kamit Klien berbicara sendiri seperti } \\
\text { - Kda dunianya } \\
\text { - Klien berbicara ngawur juga sering senyum- } \\
\text { senyum sendiri }\end{array}$ & $\begin{array}{lll}\text { Gangguan persepsi sensori : } & \\
\text { Halusinasi } & & \\
\end{array}$ \\
\hline 2 & $\begin{array}{l}\text { DS : } \\
\text { - Klien mengatakan ia sibuk } \\
\text { bekerja } \\
\text { - Klien mengatakan ia } \\
\text { mempunyai bos } \\
\text { - Klien mengatakan tidak } \\
\text { mempunyai waktu yang banyak } \\
\text { dirumah untuk bersantai } \\
\text { - Klien mengatakan ia harus } \\
\text { mencari uang yang banyak } \\
\text { untuk makan } \\
\text { - Klien mengatakan bahwa ia }\end{array}$ & Waham kebesaran \\
\hline
\end{tabular}




\begin{tabular}{|l|l|}
\hline DO : \\
- Klien hanya bisa di jumpai jam \\
7 malam \\
- Klien tampak sibuk mondar- \\
mondir untuk menemui bosnya \\
- Klien sering berbicara sendiri \\
seakan-akan mempunyai dunia \\
lain
\end{tabular}

\subsection{Diagnosa Keperawatan}

1. Gangguan persepsi sensori : Halusinasi pendengaran dan penglihatan

2. Waham kebesaran

\subsection{Pohon Masalah}

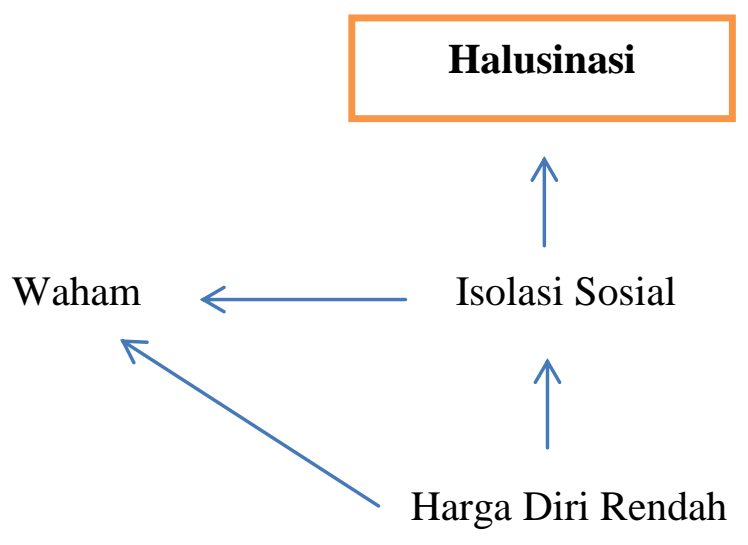

\subsection{Intervensi Keperawatan}

\begin{tabular}{|c|c|c|}
\hline No & Diagnosa Keperawatan & Intervensi \\
\hline 1 & $\begin{array}{l}\text { Gangguan persepsi sensori : } \\
\text { Halusinasi pendengaran dan } \\
\text { penglihatan }\end{array}$ & $\begin{array}{l}\text { Sp 1 : } \\
\text { 1. Mengidentifikasi isi, frekuensi, } \\
\text { waktu terjadi, situasi pencetus, } \\
\text { perasaan dan respon halusinasi } \\
\text { 2. Mengontrol halusinasi dengan cara } \\
\text { menghardik } \\
\text { Sp } 2 \text { : } \\
\text { Mengontrol halusinasi dengan cara }\end{array}$ \\
\hline
\end{tabular}




\begin{tabular}{|c|c|c|}
\hline & & $\begin{array}{l}\text { minum obat secara teratur } \\
\text { Sp } 3 \text { : } \\
\text { Mengontrol halusinasi dengan bercakap- } \\
\text { cakap dengan orang lain } \\
\text { Sp } 4 \text { : } \\
\text { Mengontrol halusinasi dengan melakukan } \\
\text { kegiatan terjadwal }\end{array}$ \\
\hline 2 & Waham & $\begin{array}{l}\text { Sp 1: } \\
\text { Latihan orientasi realita : orientasi orang, } \\
\text { tempat, dan waktu serta limgkungan } \\
\text { sekitar } \\
\text { Sp } 2 \text { : } \\
\text { Minum obat secara teratur } \\
\text { Sp } 3 \text { : } \\
\text { Melatih cara pemenuhan kebutuhan dasar } \\
\text { Sp } 4 \text { : } \\
\text { Melatih kemampuan positif yang di } \\
\text { miliki }\end{array}$ \\
\hline
\end{tabular}

\subsection{Implementasi dan Evaluasi}

\begin{tabular}{|c|c|c|}
\hline Hari/Tgl & Implementasi & Evaluasi \\
\hline $\begin{array}{l}\text { Rabu/17-2- } \\
2021\end{array}$ & $\begin{array}{l}\text { 1. Data } \\
\text { - Keluarga mengatakan klien } \\
\text { sering berbicara sendiri dan } \\
\text { tertawa sendiri } \\
\text { - Klien sering mendengar } \\
\text { suara-suara yang } \\
\text { menyuruhnya untuk pergi } \\
\text { bekerja } \\
\text { - Klien terkadang tampak } \\
\text { senang ketika halusinasinya } \\
\text { dating } \\
\text { - Klien sering mendengar } \\
\text { suara-suara ketika pagi hari, } \\
\text { dan sebelum tidur malam } \\
\text { klien sering berbicara sendiri } \\
\text { terlebih dahulu } \\
\text { 2. Diagnosa Keperawatan }\end{array}$ & $\begin{array}{l}\text { S : Klien mengatakan } \\
\text { sudah memahami apa yang } \\
\text { sudah di ajarkan } \\
\mathrm{O}: \\
\text { - Klien belum mampu } \\
\text { mengenali halusinasi } \\
\text { - Klien mampu } \\
\text { menghardik dengan } \\
\text { bantuan } \\
\text { A Klien tidak minum obat } \\
\text { pendengaran } \\
\text { penglihatan } \\
\text { P : belum teratasi }\end{array}$ \\
\hline
\end{tabular}




\begin{tabular}{|c|c|c|}
\hline & $\begin{array}{l}\text { Gangguan persepsi sensori : } \\
\text { Halusinasi pendengaran dan } \\
\text { penglihatan } \\
\text { 3. Tindakan Keperawatan : } \\
\text { Sp } 1 \text { : } \\
\text { 1) Mengidentifikasi isi, } \\
\text { frekuensi, waktu terjadi, } \\
\text { situasi pencetus, perasaan } \\
\text { dan respon halusinasi } \\
\text { 2) Mengontrol halusinasi } \\
\text { dengan cara menghardik } \\
\text { Sp } 2 \text { : } \\
\text { Mengontrol halusinasi dengan } \\
\text { cara minum obat secara teratur } \\
\text { 4. Rencana Tindak Lanjut : } \\
\text { Sp } 3 \text { : } \\
\text { Mengontrol halusinasi dengan } \\
\text { bercakap-cakap dengan orang } \\
\text { lain } \\
\text { Sp } 4 \text { : } \\
\text { Mengontrol halusinasi dengan } \\
\text { melakukan kegiatan terjadwal }\end{array}$ & \\
\hline $\begin{array}{l}\text { Kamis/18- } \\
2-2021\end{array}$ & $\begin{array}{l}\text { 1. Data } \\
\text { Tanda dan Gejala } \\
\text { - Klien masih mendengar } \\
\text { suara-suara dan belum } \\
\text { mampu mengendalikannya } \\
\text { - Klien tampak berbicara } \\
\text { sendiri } \\
\text { - Klien tampak asik dengan } \\
\text { dunianya sendiri } \\
\text { 2. Diagnosa Keperawatan : } \\
\text { Gangguan persepsi sensori : } \\
\text { Halusinasi pendengaran dan } \\
\text { penglihatan } \\
\text { 3. Tindakan Keperawatan : } \\
\text { Sp } 3 \text { : } \\
\text { Mengontrol halusinasi dengan }\end{array}$ & $\begin{array}{l}\text { S : Klien tampak biasa saja } \\
\text { dan cuek } \\
\text { O : } \\
\text { - Klien mampu } \\
\text { menghardik dengan } \\
\text { bantuan } \\
\text { - Tidak minum obat } \\
\text { - Klien mampubercakap- } \\
\text { cakap dengan orang } \\
\text { lain dengan bantuan } \\
\text { - Klien mampu } \\
\text { melakukan kegiatan } \\
\text { terjadwal seperti } \\
\text { membersihkan halaman } \\
\text { rumah, pergi dengan } \\
\text { abang klien berjalan- }\end{array}$ \\
\hline
\end{tabular}




\begin{tabular}{|c|c|c|}
\hline & $\begin{array}{l}\text { bercakap-cakap dengan orang } \\
\text { lain } \\
\text { Sp } 4 \text { : } \\
\text { Mengontrol halusinasi dengan } \\
\text { melakukan kegiatan terjadwal } \\
\text { 4. Rencana Tindak Lanjut : } \\
\text { Memberikan kembali terapi SP } \\
\text { 1-SP } 4\end{array}$ & $\begin{array}{l}\text { jalan, membersihkan } \\
\text { rumah dengan bantuan } \\
\text { A : Halusinasi } \\
\text { pendengaran } \\
\text { penglihatan } \\
\text { P : Masalah belum teratasi, } \\
\text { intervensi di lanjutkan }\end{array}$ \\
\hline $\begin{array}{l}\text { Jumat/19-2- } \\
2021\end{array}$ & $\begin{array}{l}\text { 1. Data } \\
\text { - Klien sering mendengar } \\
\text { suara-suara yang } \\
\text { menyuruhnya untuk pergi } \\
\text { bekerja } \\
\text { - Klien terkadang tampak } \\
\text { senang ketika halusinasinya } \\
\text { dating } \\
\text { - Klien sering mendengar } \\
\text { suara-suara ketika pagi hari, } \\
\text { dan sebelum tidur malam } \\
\text { klien sering berbicara sendiri } \\
\text { terlebih dahulu } \\
\text { 2. Diagnosa Keperawatan } \\
\text { Gangguan persepsi sensori : } \\
\text { Halusinasi pendengaran dan } \\
\text { penglihatan } \\
\text { 3. Tindakan Keperawatan : } \\
\text { Sp } 1 \text { : } \\
\text { 1) Mengidentifikasi } \\
\text { frekuensi, waktu terjadi, } \\
\text { situasi pencetus, perasaan } \\
\text { dan respon halusinasi } \\
\text { 2) Mengontrol } \\
\text { dengan cara menghardik } \\
\text { Sp } 2 \text { : } \\
\text { Mengontrol halusinasi dengan } \\
\text { cara minum obat secara teratur } \\
\text { Rencana Tindak Lanjut : } \\
\text { Sp } 3 \text { : }\end{array}$ & 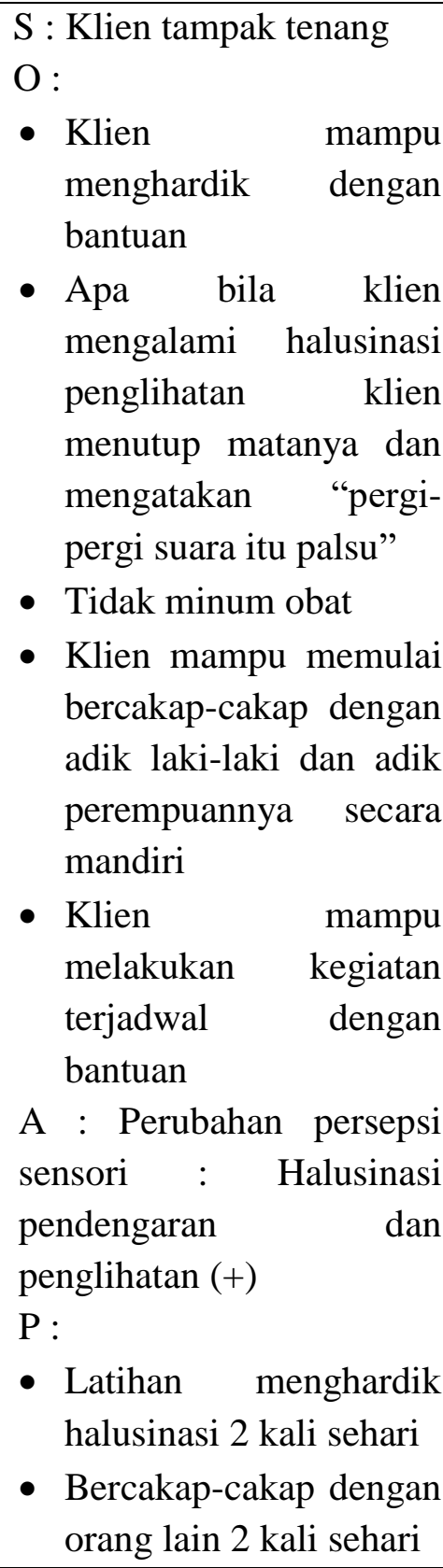 \\
\hline
\end{tabular}




\begin{tabular}{|c|c|c|}
\hline & $\begin{array}{l}\text { Mengontrol halusinasi dengan } \\
\text { bercakap-cakap dengan orang } \\
\text { lain } \\
\text { Sp 4: } \\
\text { Mengontrol halusinasi dengan } \\
\text { melakukan kegiatan terjadwal }\end{array}$ & \\
\hline $\begin{array}{l}\text { Sabtu/20-2- } \\
2021\end{array}$ & $\begin{array}{l}\text { 1. Data } \\
\text { Tanda dan Gejala } \\
\text { - Klien masih mendengar } \\
\text { suara-suara dan sudah } \\
\text { mampu mengendalikannya } \\
\text { dengan cara menghardik } \\
\text { - Klien tampak berbicara } \\
\text { sendiri } \\
\text { - Klien tampak asik dengan } \\
\text { dunianya sendiri } \\
\text { 2. Diagnosa Keperawatan : } \\
\text { Gangguan persepsi sensori : } \\
\text { Halusinasi pendengaran dan } \\
\text { penglihatan } \\
\text { 3. Tindakan Keperawatan: } \\
\text { Sp 3: } \\
\text { Mengontrol halusinasi dengan } \\
\text { bercakap-cakap dengan orang } \\
\text { lain } \\
\text { Sp } 4 \text { : } \\
\text { Mengontrol halusinasi dengan } \\
\text { melakukan kegiatan terjadwal } \\
\text { 4. Rencana Tindak Lanjut: } \\
\text { Follow up dan evaluasi SP 1-Sp } \\
\text { 4 Gangguan persepsi sensori : } \\
\text { Halusinasi pendengaran dan } \\
\text { penglihatan }\end{array}$ & $\begin{array}{l}\text { S : Klien tampak tenang } \\
\text { O : } \\
\text { - Klien mampu } \\
\text { menghardik dengan } \\
\text { mandiri } \\
\text { - Apa bila klien } \\
\text { mengalami halusinasi } \\
\text { penglihatan klien } \\
\text { menutup matanya dan } \\
\text { mengatakan "pergi- } \\
\text { pergi suara itu palsu" } \\
\text { - } \text { Klien tidak minum obat } \\
\text { secara teratur lagi } \\
\text { - Klien mampu memulai } \\
\text { bercakap-cakap dengan } \\
\text { adik laki-laki dan adik } \\
\text { perempuannya secara } \\
\text { mandiri } \\
\text { - Klien } \\
\text { melakukan kegiatan } \\
\text { terjadwal seperti } \\
\text { menyapu halaman } \\
\text { rumah dengan motivasi } \\
\text { A : Perubahan persepsi } \\
\text { sensori : Halusinasi } \\
\text { pendengaran r dan } \\
\text { penglihatan (+) } \\
\text { P : } \\
\text { - Latihan menghardik } \\
\text { - halusinasi } 2 \text { kali sehari } \\
\text { - Bercakap-cakap dengan } \\
\text { orang lain 2 kali sehari }\end{array}$ \\
\hline
\end{tabular}




\begin{tabular}{|l|l|l|}
\hline & $\begin{array}{l}\bullet \text { Melakukan kegiatan } \\
\text { terjadwal 1 kali sehari } \\
\text { yaitu menyapu halaman } \\
\text { rumah }\end{array}$ \\
\hline
\end{tabular}




\section{BAB 4}

\section{PEMBAHASAN}

Setelah penulis melaksanakan asuhan keperawatan kepada Tn. L dengan gangguan sensori persepsi: halusinasi diJalan Amal Luhur Gang Semar, Kec. Medan Helvetia, maka penulis pada $\mathrm{BAB}$ ini akan membahaskesenjangan antara teoritis dengan tinjauan kasus. Pembahasan dimulai melalui tahapan proses keperawatan yaitu pengkajian, diagnosa keparawatan, perencanaan, pelaksanaan dan evaluasi.

\subsection{Pengkajian}

Pada pembahasan ini diuraikan tentang hasil pelaksanaan tindakan keperawatan dengan pemberian terapi generalis pada klien halusinasi pendengaran dan penglihatan. Pembahasan menyangkut analisis hasil penerapan terapi generalis terhadap masalah keperawatan halusinasi pendengaran dan penglihatan. Tindakan keperawatan didasarkan pada pengkajian dan diagnosis keperawatan yang terdiri dari tindakan generalis yang dijabarkan sebagai berikut :

Tahap pengkajian pada klien halusinasi dilakukan interaksi perawat-klien melalui komunikasi terapeutik untuk mengumpulkan data dan informasi tentang status kesehatan klien. Pada proses pengkajian, data penting yang perlu didapatkan adalah jenis dan isi halusinasi, waktu, frekuensi, dan situasi yang menyebabkan halusinasi, respons terhadap halusinasi (Keliat dkk, 2016).

Selama pengkajian dilakukan pengumpulan data dari beberapa sumber, yaitu dari pasien dan keluarga pasien. Maka penulis melakukan pendekatan kepada pasien dan keluarga pasien melalui komunikasi terapeutik yang lebih terbuka membantu pasien untuk memecahkan perasaannya dan juga melakukan observasi kepada pasien.

Adapun upaya tersebut yaitu:

a. Melakukan pendekatan dan membina hubungan saling percaya diri pada klien agar klien lebih terbuka dan lebih percaya dengan menggunakan perasaan. 
b. Mengadakan pengkajian klien dengan wawancara

Dalam pengkajian ini, penulis menemukan kesenjangan karena ditemukan. Pada kasus Tn. Lklien mendengar suara-suara aneh, mondar-mandir, terkadang tertawa dan tersenyum sendiri dan lain-lain. Gejala gejala yang muncul tersebut tidak semua mencakup dengan yang ada di teori klinis dari halusnasi (Keliat, 2014). Akan tetapi terdapat faktor predisposisi maupun presipitasi yang menyebabkan kekambuhan penyakit yang dialami olehTn. L

Tindakan keperawatan terapi generalis yang dilakukan pada Tn. L adalah strategi pertemuan pertama sampai pertemuan empat. Strategi pertemuan pertama meliputi mengidentifikasi isi, frekuensi, jenis, dan respon klien terhadap halusinasi serta melatih cara menghardik halusinasi. Strategi pertemuan kedua yang dilakukan pada Tn. Lmeliputi melatih cara mengendalikan dengan bercakap-cakap kepada orang lain. Strategi pertemuan yang ketiga adalah menyusun jadwal kegiatan bersama-sama dengan klien. Strategi pertemuan keempat adalah mengajarkan dan melatih Tn. Lcara minum obat yang teratur.

\subsection{Diagnosa Keperawatan}

Diagnosa keperawatan merupakan suatu penilaian klinis mengenai respons klien terhadap masalah kesehatan atau proses kehidupan yang dialaminya baik yang berlangsung actual maupun potensial. Diagnosis keperawatan bertujuan untuk mengidentifikasi respons klien individu, keluarga dan komunitas terhadap situasi yang berkaitan dengan kesehatan (Fadhillah, 2017). Diagnosa yang muncul pada kasus Tn. L yang meliputi: halusinasi, waham kebesaran. Dari hal tersebut di atas dapat dilihat terjadi kesamaan antara teori dan kasus. Dimana semua diagnosa pada teori muncul pada kasus Tn. L. 


\subsection{Implementasi}

Implementasi atau disebut tindakan keperawatan merupakan rangkaian perilaku atau aktivitas yang dikerjakan oleh perawat untuk mengimplementasikan intervensi keperawatan. Tindakan-tindakan pada intervensi keperawatan terdiri atas observasi, terapeutik, edukasi dan kolaborasi (Fadhillah, 2018). Pada tahap implementasi, penulis hanya mengatasi 1 masalah keperawatan yakni: diagnosa keperawatan halusinasi. Pada diagnosa keperawatan gangguan persepsi sensori halusinasi dilakukan strategi pertemuan yaitu mengidentifikasi isi, frekuensi, waktu terjadi, perasaan, respon halusinasi. Kemudian strategi pertemuan yang dilakukan yaitu latihan mengontrol halusinasi dengan cara menghardik. Strategi pertemuan yang kedua yaitu anjurkan minum obat secara teratur, strategi pertemuan yang ke tiga yaitu latihan dengan cara bercakap-cakap pada saat aktivitas dan latihan strategi pertemuan ke empat yaitu melatih klien melakukan semua jadwal kegiatan.

\subsection{Evaluasi}

Setelah tindakan keperawatan, segera lakukan evaluasi. Evaluasi terhadap masalah keperawatan halusinasi meliputi kemampuan pasien halusinasi dan keluarganya dan kemampuan perawat dalam merawat pasien halusinasi (Keliat, 2012). Pada tinajauan teoritis evaluasi yang diharapkan adalah: Pasien mempercayai perawat sebagai terapis, pasien menyadari bahwa yang dialaminya tidak ada objeknya, dapat mengidentifikaasi halusinasi, dapat mengendalikan halusinasi melalui menghardik, latihan bercakap-cakap, melakukan aktivitas serta menggunakan obat secara teratur.Klien mampu mengontrol dan mengidentifikasi halusinasi, Klien mampu melakukan latihan bercakap-cakap dengan orang lain, Klien mampu melaksanakan jadwal yang telah dibuat bersama, Klien mampu memahami penggunaan obat yang benar:. Selain itu, dapat dilihat dari setiap evalusi yang dilakukan pada asuhan keperawatan, dimana terjadi penurunan gejala yang dialami oleh Tn. L dari hari kehari selama proses interaksi. 


\section{BAB 5 \\ PENUTUP}

\subsection{Kesimpulan}

Berdasarkan uraian pada pembahasan di atas, maka penulis dapat menyimpulkan bahwa :

1. Pengkajian dilakukan secara langsung pada klien dan juga dengan menjadikan status klien sebagai sumber informasi yang dapat mendukung data-data pengkajian. Selama proses pengkajian, perawat mengunakan komunikasi terapeutik serta membina hubungan saling percaya antara perawat-klien. Pada kasus Tn. Ldiperoleh bahwa klien mengalami gejala-gejala halusinasi seperti mendengar suara-suara, gelisah, sulit tidur, mondar-mandir,tidak dapat mempertahankan kontak mata, mudah marah dan lain-lain. Faktor predisposisi Tn. Lyaitu tidak mengalami gangguan jiwa sebelumnya.

2. Diagnosa keperawatan yang muncul pada kasus Tn. L Halusinasi pendengarandan penglihatan, koping individu inefektif, regimen teraupetik keluarga inefektif, dan terjadi waham kebesaran. Tetapi pada pelaksanaannya, penulis fokus pada masalah utama yaitu halusinasi pendengaran dan penglihatan.

3. Perencanaan dan implementasi keperawatan disesuaikan dengan strategi pertemuan pada pasien halusinasi pendengaran dan penglihatan.

4. Evaluasi diperoleh bahwa terjadi peningkatan kemampuan klien dalam mengendalikan halusinasi yang dialami serta dampak pada penurunan gejala halusinasi pendengaran dan penglihatan yang dialami.

\subsection{Saran}

1. Bagi Perawat

Diharapkan dapat menerapkan komunikasi terapeutik dalam pelaksanaan strategi pertemuan 1-4 pada klien dengan halusinasi sehingga dapat mempercepat proses pemulihan klien. 
2. Bagi Institusi Pendidikan

Dapat meningkatkan bimbingan praktek lapangan kepada mahasiswa profesi ners sehingga mahasiswa semakin mampu dalam melakukan asuhan keperawatan pada pasien-pasien yang mengalami halusinasi.

3. Bagi Pasien

Laporan ini diharapkan dapat menjadi acuan dan referensi dalam memberikan asuhan keperawatan pada klien dengan halusinasi pendengaran. 


\section{DAFTAR PUSTAKA}

Aldam, S. F. S., \& Wardani, I. Y. (2019). Efektifitas penerapan standar asuhan keperawatan jiwa generalis pada pasien skizofrenia dalam menurunkan gejala halusinasi. Jurnal Keperawatan Jiwa, 7(2), 165-172. https://doi.org/10.26714/jkj.7.2.2019.167-174

Pardede, J. A., Keliat, B. A., \& Yulia, I. (2015). Kepatuhan dan Komitmen Klien Skizofrenia Meningkat Setelah Diberikan Acceptance And Commitment Therapy dan Pendidikan Kesehatan Kepatuhan Minum Obat. Jurnal Keperawatan Indonesia, 18(3), 157-166. 10.7454/jki.v18i3.419

Pardede, J. A., Hamid, A. Y. S., \& Putri, Y. S. E. (2020). Application of Social Skill Training using Hildegard Peplau Theory Approach to Reducing Symptoms and the Capability of Social Isolation Patients. Jurnal Keperawatan, 12(3), 327-340. https://doi.org/10.32583/keperawatan.v12i3.782

Pardede, J. A., Irwan, F., Hulu, E. P., Manalu, L. W., Sitanggang, R., \& Waruwu, J. F. A. P. (2021, February 4). Asuhan keperawatan Jiwa Dengan Masalah Halusinasi. https://doi.org/10.31219/osf.io/fdqzn

Pardede, J. A. (2020). Family Knowledge about Hallucination Related to Drinking Medication Adherence on Schizophrenia Patient. Jurnal Penelitian Perawat Profesional, 2(4), 399-408. https://doi.org/10.37287/jppp.v2i4.183

Pardede, J. A. (2020). Family Burden Related to Coping when Treating Hallucination Patients. Jurnal Ilmu Keperawatan Jiwa, 3(4), 453-460. http://dx.doi.org/10.32584/jikj.v3i4.671

Pardede, J. A., \& Siregar, R. A. (2016). Pendidikan Kesehatan Kepatuhan Minum Obat Terhadap Perubahan Gejala Halusinasi Pada Klienskizofrenia. Mental Health, 3(1).

Damaiyanti, Iskandar. 2014. Asuhan Keperawatan Jiwa. Bandung: Refika Aditama.

Direja, S. H. Asuhan Keperawatan Jiwa. Yogyakarta: Nuha Medika

Keliat B. A, dkk. 2014. Proses Keperawatan Jiwa Edisi II. Jakarta: EGC.

Keliat B. A, Akemat. 2012. Model Praktik Keperawatan Profesional Jiwa. Jakarta: EGC.

Keliat B. A, dkk. 2016. Keperawatan Kesehatan Jiwa Komunitas. Jakarta: EGC

Kemenkes RI. 2013. Riset Kesehatan Dasar; RISKESDAS. Jakarta: Balitbang

Nyumirah, S. (2013). Peningkatan kemampuan interaksi sosial (kognitif, afektif dan perilaku) melalui penerapan terapi perilaku kognitif di $\mathrm{rsj}$ dr amino 


$$
\begin{aligned}
& \text { gondohutomo } \quad \text { semarang. Jurnal } \\
& \text { https://doi.org/10.26714/jkj.1.2.2013.\%25p }
\end{aligned} \quad \text { keperawatan jiwa, 1(2). }
$$

Prabowo, E. (2014). Konsep \& Aplikasi Asuhan Keperawatan Jiwa. Yogyakarta: Nuha Medika

Prabowo, E. (2014). Buku Ajar Keperawatan Jiwa. Yogyakarta: Nuha Medika.

Stuart, G. W., Keliat, B. A., \& Pasaribu, J. 2016. Prinsip dan praktik keperawatan kesehatan jiwa stuart. Edisi Indonesia. Singapore: Elsevier

Stuart, G.W., \& Laraia, M.T. 2005. Principle and practice of psyciatric nursin9 thed. St Louis : Mosby year book

Stuart, G. W. 2009. Buku Saku Keperawatan Jiwa. Edisi 5. Jakarta. EGC.

Fadhillah H. 2017. Standar Diagnosis Keperawatan Indonesia. Jakarta Selatan: DPP, PPNI

Fadhillah H. 2018. Standar Intervensi Keperawatan Indonesia. Jakarta Selatan: DPP, PPNI 